\title{
Ultrasound appearance of the brain in very preterm infants and neurodevelopmental outcome at 18 months of age
}

\author{
A L STEWART, R J THORBURN, P L HOPE, M GOLDSMITH, A P LIPSCOMB, AND \\ E O R REYNOLDS
}

Department of Paediatrics, University College London

SUMMARY The brains of 158 consecutively admitted very preterm infants were repeatedly examined with real time ultrasound. Abnormalities, most commonly periventricular haemorrhage, were detected in $79(50 \%)$. The 109 infants who survived were followed up until they were 16-23 months old. Major or minor neurological or developmental sequelae were found in 5 of 62 infants $(8 \%)$ with normal ultrasound scans and in an identical proportion, 2 of 25 infants ( $8 \%$ ), with uncomplicated periventricular haemorrhage. By contrast, 15 of 21 infants $(71 \%)$ whose ventricles became enlarged (with or without periventricular haemorrhage) had abnormalities at follow up. The proportion with sequelae depended on the cause and extent of the enlargement. Three of 8 infants (38\%) with mild (usually transient) ventricular distension had sequelae, compared with 3 of 4 $(75 \%)$ with hydrocephalus and 9 of $9(100 \%)$ with cerebral atrophy (2 of whom also had hydrocephalus). Adverse neurodevelopmental sequelae at follow up appeared more often to be attributable to cerebral ischaemia and infarction than to periventricular haemorrhage.

We have reported that brain ultrasound scanning of very preterm infants admitted to this neonatal unit in 1979 gave us useful information for predicting the chances of death or of neurodevelopmental abnormalities severe enough to be detectable within the first year of life in the survivors. ${ }^{1}$ We continued this study through 1980 and the survivors from both years have been followed up until they were aged between 16 and 23 months. We report the relation between the appearances of the brain as visualised by ultrasound in the neonatal period and neurodevelopmental outcome.

\section{Methods}

Infants studied. In 1979 the brains of all 95 infants admitted to this unit who were born at less than 33 weeks' gestation were studied prospectively with real time ultrasound using portable apparatus. ${ }^{23}$ The results showed that 2 overlapping groups among these very preterm infants were of especially high risk of cerebral haemorrhage or infarction leading to atrophy-infants weighing up to $1250 \mathrm{~g}$ and those who needed mechanical ventilation. ${ }^{4}$ In 1980 all 63 infants with these characteristics admitted to the unit were studied. The managemet of these infants, many of whom were seriously ill, was in general as described. ${ }^{5} 6$

Ultrasound scanning. A linear array real time ultrasound scanner (ADR 2130) with a $5 \mathrm{MHz}$ focused transducer array was used to scan the infants' brains through the skull in horizontal, coronal, and other planes, ${ }^{2} 3$ and from June 1979 through the anterior fontanelle as well. From July 1980 a $7 \mathrm{MHz}$ probe was also used and gave improved definition in scans through the fontanelle. Details of the methods and evidence that accurate information was obtained about the brain appearence have been described. ${ }^{3}$ The results of ultrasound scans were stored on videotape or Polaroid photograph, or both. Scans were performed several times during the first week of life and then once or twice weekly until the infants' discharge home or death. ${ }^{4}$ When an abnormality was diagnosed or suspected, scanning was continued at follow up.

Haemorrhages into the germinal layer or ventricles, or both, were grouped together as periventricular haemorrhage (PVH) and their extent was graded in a manner similar to that described by Papile et al. ${ }^{7}$ for 
computerised tomography. Grade I was defined as PVH confined to the germinal layer or occupying less than half of 1 or both lateral ventricles; grade II was PVH occupying more than half a lateral ventricle but not distending it; grade III was PVH distending any part of a lateral ventricle; and grade IV was haemorrhage extending from the region of the germinal layer into the brain tissue with or without intraventricular haemorrhage. We could not be certain whether grade IV haemorrhage was due to spread of bleeding from ruptured vessels in the germinal layer or to periventricular infarction, or both.

If the ventricles appeared enlarged classification depended on whether enlargement was considered to be caused primarily by altered cerebrospinal fluid (CSF) dynamics leading to distension of the ventricles, or to loss of brain tissue. A diagnosis of 'mild ventricular distension' was made when the ventricular system became distended with CSF, but not to the extent of causing an increase in the width of the bodies of the lateral ventricles to $5 \mathrm{~mm}+2 \mathrm{SD}$ over expected values for comparable normal infants admitted to our unit. ${ }^{8}$ These values were similar to those of Levene. ${ }^{9}$ If the distension regressed so that the scan appearance of the ventricular system returned to normal it was termed 'transient', but if the ventricles remained dilated it was termed 'persistent'. No infant received treatment for mild ventricular distension. A diagnosis of 'hydrocephalus' was made when the width of the bodies of the lateral ventricles increased to $\geqslant 5 \mathrm{~mm}+2 \mathrm{SD}$ above the expected value in 2 weeks or less. All the infants with hydrocephalus were treated with repeated lumbar punctures or ventriculoperitoneal shunting, or both. ${ }^{8}$ A diagnosis of cerebral atrophy was made when either persistent and usually irregular enlargement of the ventricular system gradually developed without, or several weeks after PVH, while cranial growth remained normal or delayed and there was no clinical evidence of raised intracranial pressure, or when cysts developed at the site of previous grade IV PVH. Ultrasound scanning of the 109 surviving infants was continued until a median age of 24 days (range 3-188 days).

Follow up. Three of the 109 surviving infants moved abroad aged 3-5 months. Limited information on their neurodevelopmental progress was, however, available from their parents and from their local medical attendants and psychologists. The remaining infants were assessed for growth and progress approximately 3 monthly, or more often when clinically indicated. Each infant's age was corrected for preterm birth by subtracting the number of weeks that the infant had been born before term from the chronological age. The Developmental screening inventory ${ }^{10}$ was used, neurological assessments were performed according to Amiel-Tison and Grenier, ${ }^{11}$ and ophthalmological examinations were done. A postauricular myogenic response test (PAM test), ${ }^{12}$ was carried out at 6 months of age to screen for hearing loss. Infants with abnormal responses to the PAM test were referred to a neuro-otologist for further investigation. As near as possible to 18 months of age developmental assessments were performed by a clinical psychologist, using the Griffiths baby test. ${ }^{13}$ The psychologist was given no information about the children, except their gestational age.

Statistical analysis. When the infants were discharged home clinical details and the results of ultrasound scans were coded and stored on punch cards. The results of follow up examinations were added as they became available and the data were analysed by computer, using the Statistical package for the social sciences. ${ }^{14}$ Student's $t$ test, $\chi^{2}$ with Yates's correction, and the Mann-Whitney U test were used as appropriate.

\section{Results}

The median gestational age of the 158 infants admitted to the study was 29 weeks (range 23-32 weeks) and their median birthweight was $1235 \mathrm{~g}$ (range 540-3397 g). There were 84 boys and 74 girls. Sixty five were born in University College Hospital and 93 were referred from other hospitals. Seventy nine $(50 \%)$ infants had abnormal ultrasound scan appearances, including $72(46 \%)$ with PVH. Seventeen $(22 \%)$ of the 79 infants with normal scans died compared with $34(43 \%)$ of those with abnormal scans $\left(\chi^{2}=7 \cdot 41, P<0.005\right)$. Of the latter group, 2 infants had gross neurodevelopmental abnormalities and died 11 and 24 months after birth. They were followed up fully until death and have been included as survivors in the remainder of this report.

Survivors. Clinical characteristics of the surviving infants are summarised in Table 1 . Infants with abnormal ultrasound appearances were significantly lighter and less mature than those with normal scans. The incidence of abnormality (usually PVH) was greater in infants referred from other hospitals, in infants delivered vaginally rather than by caesarean section, in infants with deficient coagulation status, and in those with hyaline membrane disease, or who needed mechanical ventilation, or developed a pneumothorax. ${ }^{4}$

Follow up. There were 12 infants $(11 \%)$ with major neurological or developmental abnormalities likely 
Table 1 Clinical details of survivors $(n=109)$

\begin{tabular}{|c|c|c|}
\hline & \multicolumn{2}{|c|}{ Ultrasound appearance } \\
\hline & Normal $(n=62)$ & Abnormal $(n=47)$ \\
\hline $\begin{array}{l}\text { Birthweight, } \\
\text { median (range) (g) }\end{array}$ & $1360(720-2500)$ & $1190(800-2040)^{*}$ \\
\hline $\begin{array}{l}\text { Gestation, } \\
\text { median (range) (weeks) }\end{array}$ & $31(25-32)$ & $29(25-32)^{*}$ \\
\hline $\begin{array}{l}\text { Boys : girls } \\
\text { Born in UCH : referred }\end{array}$ & $\begin{array}{l}34: 28 \\
32: 30\end{array}$ & $\begin{array}{l}25: 22 \\
13: 34 \dagger\end{array}$ \\
\hline Mode of delivery & & \\
\hline $\begin{array}{l}\text { Vaginal } \\
\text { Breech }\end{array}$ & $\begin{array}{r}22 \\
9\end{array}$ & $\begin{array}{l}24 \\
11\end{array}$ \\
\hline Caesarean section & 31 & $12 \dagger$ \\
\hline $\begin{array}{l}\text { Small for gestational age } \\
\text { Apgar score }\end{array}$ & 3 & 2 \\
\hline $\begin{array}{l}<3 \text { at } 1 \text { minute } \\
<3 \text { at } 5 \text { minutes }\end{array}$ & $\begin{array}{r}15 \\
5\end{array}$ & $\begin{array}{r}19 \\
0\end{array}$ \\
\hline $\begin{array}{l}\text { Onset of spontaneous } \\
\text { breathing }>\mathbf{3 0} \text { minutes }\end{array}$ & 2 & 5 \\
\hline Deficient coagulation status 5 & 11 & $21 *$ \\
\hline Hyaline membrane disease & 25 & $35^{*}$ \\
\hline Mechanical ventilation & 33 & 39* \\
\hline $\begin{array}{l}\text { Pneumothorax } \\
\text { Plasma bilirubin }\end{array}$ & 3 & $13^{*}$ \\
\hline$>170 \mu \mathrm{mol} / 1$ & 29 & 23 \\
\hline
\end{tabular}

* $\mathrm{P}<0.005$. $+\mathrm{P}<0.025$ (for mode of delivery : difference between vaginal delivery and caesarean section).

Conversion: SI to traditional units-Plasma bilirubin: $1 \mu \mathrm{mol} / 1 \approx$ $0.058 \mathrm{mg} / 100 \mathrm{ml}$.

to affect function permanently. These abnormalities included cerebral palsy, sensorineural hearing loss, cortical blindness, retrolental fibroplasia, and overall developmental delay of sufficient severity to predict mental retardation-indicated by a developmental quotient $<70$ at 10 months of corrected age or a Griffiths general quotient $<70$ at 18 months, or both. These abnormalities were similar to those described as 'major handicap' by us in previous reports. ${ }^{115} \mathrm{~A}$ further 10 infants $(9 \%)$ had clinically detectable neurological signs of disorder that were either remediable or did not impair function. These minor disorders included abnormalities of muscle tone, strabismus, or a ventriculoperitoneal shunt in an otherwise normal child.

Table 2 shows the relation between the ultrasound appearence of the brain and both major and minor neurodevelopmental abnormalities identified during the first 18 months of life, classified primarily according to the presence and grade of PVH. Two infants with normal ultrasound scan appearances had major abnormalities and 3 had minor ones at follow up, giving a total of 5 of 62 infants (8\%). Among 47 infants with abnormal scans, 10 had major problems and 7 had minor ones giving a total of 17 of 47 infants $(36 \%)\left(\chi^{2}=11.42, P<0.001\right)$. The proportion of infants with abnormalities at follow up increased with the grade of haemorrhage and all infants in whom cerebral atrophy was diagnosed, whether or not associated with PVH, were abnormal.
Table 2 Results of ultrasound scans classified primarily by grade of periventricular haemorrhage $(P V H)$ and follow up in survivors $(n=109)$

\begin{tabular}{|c|c|c|c|c|}
\hline \multirow{2}{*}{$\begin{array}{l}\text { Ultrasound } \\
\text { appearance }\end{array}$} & \multirow{2}{*}{$\begin{array}{l}\text { No of } \\
\text { infants }\end{array}$} & \multicolumn{3}{|c|}{ Neurodevelopmental abnormality } \\
\hline & & $\begin{array}{l}\text { Major } \\
\text { No }(\%)\end{array}$ & $\begin{array}{l}\text { Minor } \\
\text { No }(\%)\end{array}$ & $\begin{array}{l}\text { Total } \\
\text { No }(\%)\end{array}$ \\
\hline $\begin{array}{l}\text { Normal } \\
\text { Abnormal }\end{array}$ & 62 & $2(3)$ & $3(5)$ & $5(8)$ \\
\hline $\begin{array}{c}\text { Haemorrhage } \\
\text { PVH grade I } \\
\text { (+ cerebral } \\
\text { atrophy) }\end{array}$ & $21 \dagger$ & $2(10) \ddagger$ & $2(10) \ddagger$ & $4(20) \dagger$ \\
\hline $\begin{array}{l}\text { PVH grade II } \\
\text { PVH grade III } \\
\text { PVH grade IV } \\
\text { (+ cerebral } \\
\text { atrophy) }\end{array}$ & $\begin{array}{l}12 \\
5 \\
4 \S\end{array}$ & $\begin{array}{l}2(17) \\
1(20) \\
4(100) \S\end{array}$ & $\begin{array}{l}1(8) \\
1(20) \\
0\end{array}$ & $\begin{array}{l}3(25) \\
2(40) \\
4(100) \S\end{array}$ \\
\hline $\begin{array}{l}\text { Intradural* } \\
\text { No haemorrhage }\end{array}$ & 1 & 0 & 0 & 0 \\
\hline $\begin{array}{l}\text { Mild ventricular } \\
\text { distension } \\
\text { (transient) }\end{array}$ & 1 & 0 & 1 & 1 \\
\hline $\begin{array}{l}\text { Cerebral } \\
\text { atrophy }\end{array}$ & 3 & $1(33)$ & $2(67)$ & $3(100)$ \\
\hline
\end{tabular}

${ }^{*} 1 \mathrm{~cm}$ in diameter, extending laterally from interhemispheric fissure. Infants who had cerebral atrophy as well as PVH- $+=2$ infants; $\ddagger=$ 1 infant; $8=4$ infants. Six infants with grade I-IV PVH survived with hydrocephalus -4 were treated with ventriculoperitoneal shunts. Seven infants with grade I-III PVH had mild ventricular distension.

Table 3 Ultrasound appearances classified primarily by ventricular enlargement, and follow up in survivors $(n=109)$

\begin{tabular}{|c|c|c|c|c|}
\hline \multirow[t]{2}{*}{ Ultrasound appearance } & \multirow[t]{2}{*}{$\begin{array}{l}\text { No of } \\
\text { infants }\end{array}$} & \multicolumn{3}{|c|}{$\begin{array}{l}\text { Neurodevelopmental } \\
\text { abnormality }\end{array}$} \\
\hline & & $\begin{array}{l}\text { Major } \\
(\%)\end{array}$ & $\begin{array}{l}\text { Minor } \\
(\%)\end{array}$ & $\begin{array}{l}\text { Total } \\
(\%)\end{array}$ \\
\hline Normal & 62 & $2(3)$ & $3(5)$ & $5(8)$ \\
\hline $\begin{array}{l}\text { Abnormal } \\
\text { Uncomplicated PVH, } \\
\text { grade I } \\
\text { grade II } \\
\text { grade III }\end{array}$ & $\begin{array}{r}17 \\
7 \\
1 \\
25\end{array}$ & $\begin{array}{l}1 \\
0 \\
0 \\
1(4)\end{array}$ & $\begin{array}{l}1 \\
0 \\
0 \\
1(4)\end{array}$ & $2(8)$ \\
\hline Intradural haemorrhage & 1 & $\mathbf{0}$ & 0 & 0 \\
\hline $\begin{array}{l}\text { Ventricular enlargement } \pm \text { PVI } \\
\text { Mild ventricular distension } \\
\text { alone* } \\
\text { + PVH, grade I } \\
\text { + PVH, grade II } \\
\text { + PVH, grade III }\end{array}$ & $\begin{array}{r}\mathrm{H} \\
\\
1 \\
2 \\
3 \\
2 \\
8\end{array}$ & $\begin{array}{l}0 \\
0 \\
2 \\
0 \\
2(25)\end{array}$ & $\begin{array}{l}1 \\
0 \\
0 \\
0 \\
1(13)\end{array}$ & $3(38)$ \\
\hline $\begin{array}{l}\text { Hydrocephalus + PVH, } \\
\text { grade II } \\
\text { grade III }\end{array}$ & $\begin{array}{l}2 \\
2 \\
4\end{array}$ & $\begin{array}{l}0 \\
1 \\
1(25)\end{array}$ & $\begin{array}{l}1 \\
1 \\
2(50)\end{array}$ & $3(75)$ \\
\hline $\begin{array}{c}\text { Cerebral atrophy alone } \\
\text { + PVH, grade I } \\
\text { grade IV }\end{array}$ & $\begin{array}{l}3 \\
2 \\
2 \\
7\end{array}$ & $\begin{array}{l}1 \\
1 \\
2 \\
4\end{array}$ & $\begin{array}{l}2 \\
1 \\
0 \\
3\end{array}$ & $7(100)$ \\
\hline $\begin{array}{l}\text { Hydrocephalus + cerebral } \\
\text { atrophy + PVH, grade IV }\end{array}$ & $\begin{array}{l}2 \\
2\end{array}$ & $\begin{array}{l}2 \\
2(100)\end{array}$ & $\begin{array}{l}0 \\
0\end{array}$ & $2(100)$ \\
\hline
\end{tabular}

* Transient in 7 infants, persistent in 1, who had a grade I PVH and was normal at follow up.

PVH = periventricular haemorrhage. 
The sensitivity of prediction by ultrasound appearance of infants with neurological or developmental sequelae at 18 months, defined as the percentage of abnormal infants correctly identified as a result of an abnormal scan, ${ }^{16}$ was $77 \%$ (17 of 22 infants). The specificity, defined as the percentage of normal infants correctly identified on the basis of a normal scan, was $66 \%$ (57 of 87). When infants with grade I PVH were grouped with those with normal scans, 9 of 83 infants $(11 \%)$ had adverse sequelae at follow up, whereas 13 of 26 infants $(50 \%)$ with grade II-IV PVH or other lesions had sequelae $\left(\chi^{2}=16.49, P<0.0005\right)$. Grouping the infants in this way improved recognition of normal infants, giving a specificity of $85 \%$ (74 of 87$)$ but not that of abnormal infants, since the sensitivity fell to $59 \%$ (13 of 22).

The relation between neonatal cerebral ultrasound appearance and outcome has been presented differently in Tables 3-6. Here infants were classified according to whether their ultrasound scans were normal, showed PVH without any other abnormality (defined as uncomplicated PVH), or showed ventricular enlargement, with or without PVH, caused by either distension with CSF or cerebral atrophy. The incidence of abnormality at follow up was no

Table 4 Ultrasound appearances and status at follow up in the 12 children with major neurodevelopmental abnormalities

\begin{tabular}{|c|c|}
\hline Case No and ultrasound appearance & Neurodevelopmental status \\
\hline $\begin{array}{l}\text { Normal } \\
1^{*}\end{array}$ & $\begin{array}{l}\text { Spastic diplegia; DQ 109, GQ } 88 \\
\text { Athetoid cerebral palsy; bilateral SNHL; DQ 79, GQ } 63 \\
\text { (kernicterus) }\end{array}$ \\
\hline $\begin{array}{l}\text { Uncomplicated PVH } \\
3 \quad \text { PVH grade I L } \\
\text { Ventricular enlargement } \pm \text { PVH } \\
\text { Mild ventricular distension }\end{array}$ & Klippel-Feil; DQ 55, GQ 75 \\
\hline $\begin{array}{ll}4 & \text { Transient; PVH grade I R, grade II L } \\
5 & \text { Transient; PVH grade II R + L } \\
\text { Hydrocephalus } & \end{array}$ & $\begin{array}{l}\text { Bilateral SNHL; DQ 76, GQ } 81 \\
\text { Bilateral SNHL; DQ 97, GQ } 92\end{array}$ \\
\hline $\begin{array}{l}6 \\
\text { Cerebral atrophy }\end{array}$ & VP shunt; SNHL R; RLF and myopia R; DQ 96, GQ 106 \\
\hline $7 \quad$ Loss of brain tissue $\mathrm{R}+\mathrm{L} ;$ no $\mathrm{PVH}$ & $\begin{array}{l}\text { Quadriplegia; cortical blindness; } D Q \approx 10, \text { GQ } 30 \text {; died } \\
\text { aged } 24 \text { months }\end{array}$ \\
\hline $\begin{aligned} 8 & \text { Loss of brain tissue } R+L ; P V H \text { grade I } R \\
9 & \text { Loss of brain tissue } R+L ; \text { PVH grade IV } R \text { with cyst } \\
10 & \text { PVH grade IV } L \text { with cyst }\end{aligned}$ & $\begin{array}{l}\text { Quadriplegia; strabismus R+L; DQ 50, GQ } 52 \\
\text { Quadriplegia; DQ 57; died aged } 11 \text { months } \\
\text { Double hemiparesis R > L; DQ 89, GQ } 93\end{array}$ \\
\hline
\end{tabular}

*Scanned to day 3 only; †emigrated aged 13 weeks but progress reported by local doctors.

PVH = periventricular haemorrhage; VP = ventriculoperitoneal; SNHL = sensorineural hearing loss; $R L F=$ retrolental fibroplasia; $R=$ right hemisphere; $\mathrm{L}=$ left hemisphere; $\mathrm{DQ}=$ developmental quotient; $\mathrm{GQ}=$ Griffiths general quotient.

Table 5 Ultrasound appearances and status at follow up in 10 children with minor neurological abnormalities

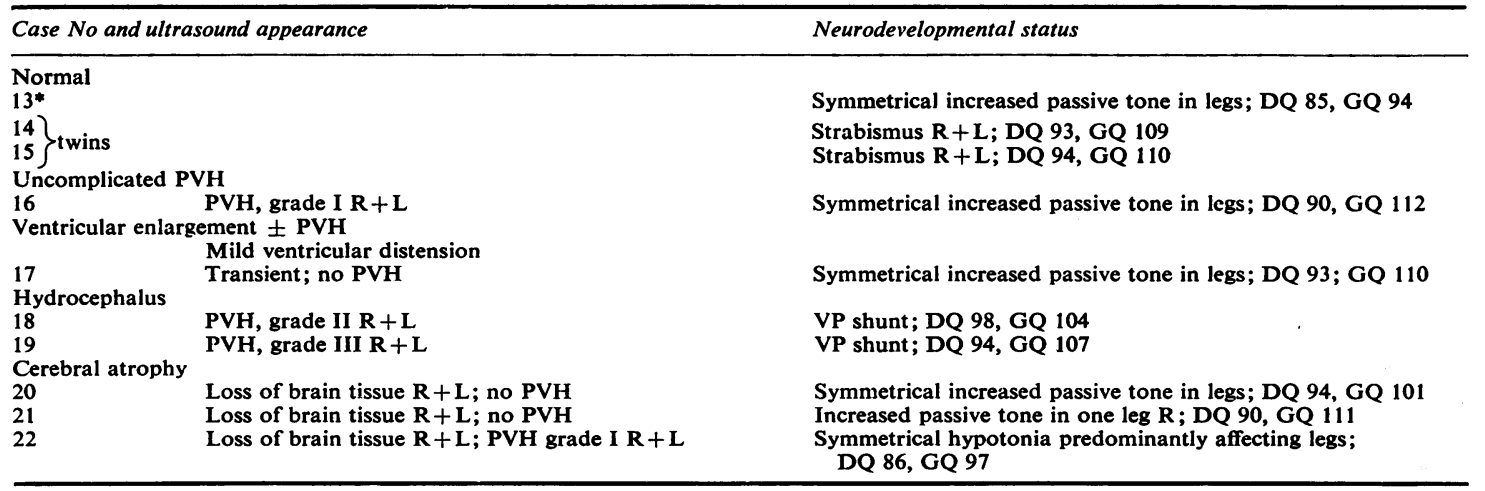

*Scanned to day 6 only; $R=$ right hemisphere; $L=$ left hemisphere; PVH = periventricular haemorrhage; VP = ventriculoperitoneal; DQ = developmental quotient; $\mathrm{GQ}=$ Griffiths general quotient. 
Table 6 Ultrasound appearances and developmental quotient (DQ) at 8-14 months (median 10 months) and Griffiths general quotient $(G Q)$ at 16-23 months (median 18 months) of corrected age $(n=109)$

\begin{tabular}{|c|c|c|c|c|c|c|c|c|c|c|c|c|c|c|}
\hline \multirow{3}{*}{ Ultrasound appearance } & \multirow{3}{*}{$\begin{array}{l}\text { No of } \\
\text { infants }\end{array}$} & \multicolumn{13}{|c|}{$D Q$ and $G Q$} \\
\hline & & \multicolumn{2}{|c|}{$<70$} & \multicolumn{2}{|c|}{$70-84$} & \multicolumn{2}{|c|}{$85-99$} & \multicolumn{2}{|c|}{$\begin{array}{l}100-114 \\
(>100 \\
\text { for } D Q)\end{array}$} & \multirow{2}{*}{$\begin{array}{l}115-131 \\
\overline{G Q}\end{array}$} & \multicolumn{2}{|c|}{$\begin{array}{l}\text { Not } \\
\text { tested }\end{array}$} & \multicolumn{2}{|l|}{ Median (range) } \\
\hline & & $D Q$ & $G Q$ & $\boldsymbol{D Q}$ & $\boldsymbol{G Q}$ & $D Q$ & $\boldsymbol{G} \boldsymbol{Q}$ & $D Q$ & $\boldsymbol{G Q}$ & & $D Q$ & $\boldsymbol{G} Q$ & $D Q$ & $G Q$ \\
\hline \multicolumn{13}{|l|}{ Abnormal } & $99(79->100)$ & $103(63-121)$ \\
\hline Uncomplicated PVH & 25 & $1^{*}$ & - & - & $2^{*}$ & 15 & 6 & 7 & 13 & 2 & 2 & 2 & $99(55->100)$ & $107(75-119)$ \\
\hline $\begin{array}{l}\text { Intradural haemorrhage } \\
\text { Ventricular enlargement } \\
\quad \pm \text { PVH }\end{array}$ & 1 & 一 & 一 & 一 & - & 1 & 一 & - & 1 & - & 一 & 一 & (95) & (101) \\
\hline Mild ventricular distension & 8 & - & - & $1^{*}$ & $1^{*}$ & $5 *$ & $3^{*}$ & 2 & 4 & - & - & - & $97(74->100)$ & $99(81-110)$ \\
\hline Hydrocephalus & 4 & - & - & - & - & 3* & - & 1 & $4^{*}$ & - & - & - & $95(91->100)$ & $105(104-109)$ \\
\hline $\begin{array}{l}\text { Cerebral atrophy } \\
\text { Hydrocephalus }\end{array}$ & 7 & $3^{* * *}$ & $2 * *$ & 一 & - & $4^{*}$ & $2 *$ & - & 2 & 一 & - & $1 * \dagger$ & $86(\sim 10->100)$ & $95(\sim 30-111)$ \\
\hline + cerebral atrophy & 2 & - & - & 一 & - & $1^{*}$ & - & - & $1^{*}$ & - & $1^{*}$ & $1^{*}$ & (96) & (105) \\
\hline
\end{tabular}

*Each asterisk represents one infant classified as having major neurodevelopmental abnormalities (Tables III-V). †Died aged 11 months. PVH $=$ periventricular haemorrhage.

different $(8 \%)$ in infants with uncomplicated PVH than in those with normal scans. When ventricular enlargement was present 15 of 21 infants $(71 \%)$ had sequelae, as opposed to 7 of 87 infants $(8 \%)$ with normal scans or uncomplicated PVH, or both $\left(\chi^{2}=38.08, P<0.0005\right)$. The sensitivity of this classification was $68 \%(15$ of 22$)$ and the specificity was $93 \%$ (81 of 87$)$. When major abnormalities alone were considered at follow up calculations of sensitivity and specificity gave results similar to those described above for all abnormalities.

Tables 4 and 5 give details of neonatal cerebral ultrasound scan appearances and the abnormalities detected at follow up in all 22 abnormal children. The developmental quotients (DQ) at 8-14 months (median 10 months) of age and the Griffiths general quotients (GQ) at 16-23 months (median 18 months) are given in Table 6.

\section{Discussion}

Our main purpose was to explore the relation between neonatal brain ultrasound appearances and neurodevelopmental status at 18 months of age. In our earlier study ${ }^{1}$ we grouped arbitrarily infants with normal ultrasound scans or isolated grade I PVH together and found that they fared better during the first year of life than those infants with more extensive intracranial lesions, caused by either haemorrhage or infarction. Adopting a similar approach, our present data yielded comparable results, giving a sensitivity (correct identification of abnormal infants by ultrasound) of $59 \%$ and a specificity (correct identification of normal infants) of $85 \%$. A sensitivity of $59 \%$ implies that $41 \%$ of the infants who later proved to be abnormal were not identified by ultrasound.

To find out whether better prediction by ultrasound of infants who were later found to have sequelae was possible, we reclassified the ultrasound findings. We assumed that there were no strong a priori reasons for supposing that uncomplicated PVH caused adverse sequelae but that enlargement of the ventricles, due either to distension with CSF (causing stretching of brain tissue) or to cerebral atrophy might well have adverse neurodevelopmental consequences. Tables 3-5 show that this approach was justified. The prevalence of abnormality at follow up was not different $(8 \%)$ in infants with uncomplicated PVH compared with infants with normal ultrasound scans and we conclude that uncomplicated PVH is a relatively innocuous lesion in surviving infants. By contrast, when ventricular enlargement was diagnosed by ultrasound the prognosis was often bad, since $71 \%$ of the infants had abnormalities at follow up. Classifying infants according to the presence or absence of ventricular enlargement gave a specificity of $68 \%$ and a sensitivity of $93 \%$. Hence, prediction of outcome based on ventricular enlargement was more precise than prediction based primarily on the grade of haemorrhage. This conclusion is consistent with the report of Palmer et al., ${ }^{17}$ who found that infants with PVH together with ventricular enlargement were not progressing as well at 1 year of age as infants with PVH alone. These authors did not, however, include infants who developed enlarged ventricles without PVH.

In our study the likelihood of abnormality at follow up increased with the extent and cause of the 
ventricular enlargement. Three of 8 infants (38\%) with mild ventricular distension had sequelae, compared with 3 of $4(75 \%)$ with hydrocephalus and 9 of 9 infants $(100 \%)$ with cerebral atrophy ( 2 of whom also had hydrocephalus).

In only 1 of the 8 infants with mild ventricular distension was the distension persistent and this infant appeared normal at follow up. The distension regressed by 3-17 weeks (median 6 weeks) in the other 7. Two of these 7 infants (Table 6, cases 4 and 5) were found to have bilateral sensorineural hearing loss at follow up. The cause-as in 2 other infants with substantial intraventricular haemorrhage (cases 6 and 12)-may have been bleeding into the inner ear, ${ }^{18}$ although ischaemic damage to auditory pathways and the adverse influences of bilirubin (maximum plasma values 180-270 $\mu \mathrm{mol} / 1(10 \cdot 53-$ $15.79 \mathrm{mg} / 100 \mathrm{ml}$ )) and gentamicin (maximum trough levels $<1-3.8 \mathrm{mg} / \mathrm{l}$ ) were also possibilities.

The 4 infants with hydrocephalus, but not cerebral atrophy, all had normal DQs and GQs at follow up (Table 6). One (Table 4, case 6) had unilateral deficits of vision and hearing, but the other 3 appeared to be developing normally, although 2 (Table 5, cases 18 and 19) were classified as having minor neurodevelopmental abnormalities solely because of the presence of ventriculoperitoneal shunts.

The outcome for the 9 infants with cerebral atrophy was dismal. All 9 were abnormal and 6 of them (including 2 who died during the study) had major abnormalities. In 3 of these 6 infants (Table 4, cases 10,11 , and 12) cerebral atrophy appeared to be mainly or entirely confined to the site of a previous grade IV PVH: all 3 had serious neurological sequelae but normal DQs and GQs. The other 3 infants with major abnormalities (Table 4, cases 7 , 8 , and 9) had severe overall developmental delay as well as gross neurological abnormalities affecting all 4 limbs. The extensive bilateral cerebral atrophy present in these 3 infants must have been mainly caused by cerebral infarction.

The remaining 3 infants of the 9 with cerebral atrophy (Table 5, cases 20,21, and 22) had minor disorders of muscle tone mainly affecting the legs. The most likely explanation for these signs was periventricular infarction (periventricular leucomalacia). ${ }^{19}$ It is interesting that 4 other infants without diagnosed cerebral atrophy (Table 4, case 1; Table 5, cases 13,14, and 17) had symmetrical signs of increased passive tone mainly affecting the legs, including 1 infant with frank spastic diplegia. These 4 infants may also have had periventricular infarction, not identified with our ultrasound scanner as cerebral atrophy.
Main causes of neurodevelopmental abnormalities at follow up

The 22 infants with sequelae at follow up may be assigned to 3 groups according to the most likely main cause of their abnormalities. Firstly, there were 5 infants with hydrocephalus and 1 with asymmetrical cerebral palsy without other abnormalities after grade IV PVH in whom it was possible to conclude that haemorrhage was largely responsible for the adverse outcome. These are the infants in cases 6,10 , $11,12,18$, and 19 in Tables 4 and 5. Haemorrhage may also have been responsible for sensorineural hearing loss in another 2 infants (cases 4 and 5), although ischaemia and other influences were not ruled out. It is probable that sequelae in a second group of 10 infants (cases 1, 7, 8, 9, 13, 14, 17, 20, 21, and 22) were mainly or entirely due to ischaemia and infarction rather than haemorrhage. Although 4 of them had PVH, this was not sufficiently serious to account for their signs at follow up. The third group was a miscellaneous one. None of the children's abnormalities seemed to be caused by haemorrage or ischaemia-1 had kernicterus (case 2), a pair of twins had bilateral strabismus without refractive errors (cases 14 and 15), and the fourth infant had Klippel-Feil syndrome (case 3). The latter infant was, however, moderately retarded at follow up and it is conceivable that she had also suffered cerebral ischaemia. We conclude that cerebral ischaemia and infarction were almost certainly responsible for more neurodevelopmental sequelae at follow up than was PVH.

We thank Mrs J Baldwyn, Mr R J Blackwell, Miss B Bradford, Mr M J Conway, Mr G Cusick, Dr G Dahlenberg, Dr S J Gould, Mr J W P Hazell, Miss N Holmes, Mr J Hungerford, Mrs D Melvin, Mrs S Owen, Dr K E Pape, Miss J Sheldrake and Miss $\mathbf{J}$ Townsend, and also the staff of this neonatal unit and of the children's outpatient department. This work was supported by the Medical Research Council and the Department of Health and Social Security.

\section{References}

1 Thorburn RJ, Lipscomb AP, Stewart AL, Reynolds EOR, Hope PL, Pape KE. Prediction of death and major handicap in very preterm infants by brain ultrasound. Lancet 1981; i: 1119-21.

2 Pape KE, Blackwell RJ, Cusick G, et al. Ultrasound detection of brain damage in preterm infants. Lancet 1979 ; i: $1261-4$.

3 Thorburn RJ, Lipscomb AP, Reynolds EOR, et al. Accuracy of imaging of the brains of newborn infants by linear-array real-time ultrasound. Early Hum Dev $1982 ; 6: 31-46$.

4 Thorburn RJ, Lipscomb AP, Stewart AL, Reynolds EOR, Hope PL. Timing and antecedents of periventricular haemorrhage and of cerebral atrophy in very preterm infants. Early Hum Dev 1982; 7: 221-38. 
5 Blake AM, Pollitzer MJ, Reynolds EOR, Referral of mothers and infants for intensive care. Br Med J 1979; ii : 414-6.

- Reynolds EOR. Neonatal intensive care and the prevention of major handicap. In: Ciba Foundation Symposium No 59. Major mental handicap: methods and costs of prevention. Amsterdam: Elsevier, 1978: 77-102.

7 Papile LA, Burstein J, Burstein R, Koffler H. Incidence and evolution of subependymal and intraventricular hemorrhage: a study of infants with birthweights less than 1500 g. J Pediatr 1978; 92: 529-34.

8 Lipscomb AP, Thorburn RJ, Stewart AL, Reynolds EOR, Hope PL. Early intervention and outcome in very preterm infants with rapidly progressive posthaemorrhagic hydrocephalus. Second special Ross Laboratories conference on perinatal intracranial hemorrhage. Syllabus. Ohio: Ross Laboratories, 1982: 840-81.

9 Levene MI. Measurement of the growth of the lateral ventricles in preterm infants with real-time ultrasound. Arch Dis Child 1981; 56: 900-4.

10 Knobloch H, Pasamanick B, Sherard ES, Jr. A developmental screening inventory for infants. Pediatrics 1966; 38: 1095-108.

11 Amiel-Tison C, Grenier A. Evaluation neurologique du nouveau-né et du nourisson. Paris: Masson, 1980.

12 Fraser JG, Conway MJ, Keene MH, Hazell JWP. The post-auricular myogenic response. J Laryngol Otol 1978; 92: 293-303.
13 Griffiths R. The abilities of babies. London: University of London Press, 1954.

14 Nie NH, Hadlaihull C, Jenkins JG, Steinbrenner K, Bent DH. Statistical package for the social sciences second edition. New York: McGraw-Hill, 1975.

15 Stewart AL, Turcan D, Rawlings G, Hart S, Gregory S. Outcome for infants at high risk of major handicap. In: Ciba Foundation Symposium No 59 (new series). Major mental handicap: methods and costs of prevention. Amsterdam: Elsevier, 1978: 151-64.

16 Haynes RB. How to read clinical journals: II To learn about a diagnostic test. Can Med Assoc J 1981; 124: 703-10.

17 Palmer P, Dubowitz LMS, Levene MI, Dubowitz V. Developmental and neurological progress of preterm infants with intraventricular haemorrhage and ventricular dilatation. Arch Dis Child 1982; 57: 748-53.

18 Spector GJ, Pettit WJ, Davis G, Strauss M, Rausbach E Fetal respiratory distress causing CNS and inner ear hemorrhage. Laryngoscope 1978; 88: 764-84.

19 Pape KE, Wigglesworth JS. Haemorrhage, ischaemia and the perinatal brain. London: Heinemann, 1979.

Correspondence to Ann L Stewart, Department of Paediatrics, University College London, The Rayne Institute, University Street, London WC1E 6JJ.

Received 14 April 1983.

\section{Notice to contributors}

Please note that revised guidelines for the submission of manuscripts have been printed inside the front cover of this journal and, in particular, that two copies of papers should be submitted. 